\title{
NUCLEIC ACID CONTENT IN LIVER OF RATS TREATED WITH POSTERIOR PITUITARY HORMONE
}

\author{
Tsutomu Hiroshige AND Shinji ITOH* \\ Department of Physiology, Hokkaido University School of Medicine, Sapporo
}

It has been well established that pentose nucleic acids (RNA) are of particular importance in protein synthesis and deoxypentose nucleic acids (DNA) play a leading part in cell division and are involved in the transmission of hereditary factors. In consideration of their biologic importance attention has been paid to hormonal influence on nucleic acid metabolism, and a number of investigations have been reported on changes in nucleic acid content in animal tissues after administrations of hormones such as cortisone, growth hormone, thyroxine, insulin, and sex hormones ${ }^{1)}$. However, no report has been appeared as to the effect of the posterior pituitary hormone, which is assumed to play a part in the control of the anterior pituitary secretion ${ }^{2}$.

The present study demonstrated that vasopressor fraction of the posterior pituitary hormone induces an increase in RNA content in liver of normal rat, but not in that of hypophysectomized one. With analogical results of changes in the width of proximal epiphyseal cartilage of tibia, the findings were discussed in the view-point of growth hormone discharge due to vasopressin.

\section{MATERIALS AND METHODS}

Young male rats of Wistar strain, weighing 90 to $150 \mathrm{~g}$, were used. The animals were maintained on rat cake. Hypophysectomy was performed by external auditory approach; hypophysectomized rats received additional 5 per cent glucose solution as drinking fluid and were kept at a constant temperature of $20^{\circ} \mathrm{C}$. for 10 days prior to experiments after the operation.

Pitressin (Parke-Davis) and Pitocin (Parke-Davis) were injected intraperitoneally in a daily dose of 400 milli-units per $100 \mathrm{~g}$ body weight for a period of 10 days. Control group of rats were injected with 0.85 per cent $\mathrm{NaCl}$ for the same period. Two groups of hypophysectomized rats were given intraperitoneally growth hormone preparations (Antuitrin Growth, Parke-Davis and Growth Hormone (Raben Typé), Nutritional Biochemical Corporation) in daily doses of 2 and 8 units per rat for 4 days. Cortisone acetate (Merck) was subcutaneously injected

Received for publication May 23, 1960.

*広重 力, 伊藤真次 
in a daily dose of $5 \mathrm{mg}$ per $100 \mathrm{~g}$ body weight for 5 days. All the animals were sacrificed by decapitation 24 hours after the last injection.

Nucleic acids in liver were extracted by the method of SCHNEIDER ${ }^{3)}$, using 12 per cent perchloric acid. DNA was determined by the color reaction of its deoxypentose with diphenylamine ${ }^{4}$ and RNA by the reaction of pentose with orcinol $^{5)}$. Amounts of nucleic acids were expressed in terms of $\mathbf{P}$ contents as DNA-P or RNA-P mg/100 g fresh tissue weight, determining $\mathrm{P}$ content by FiskeSubbarow method. Nitrogen was measured by micro-Kjeldahl method, using an aliquot of homogenates for the determination of nucleic acids. Values were expressed in terms of $\mathrm{mg} \mathrm{N}$ per mg DNA-P.

Tibias of rats were prepared for measurement of proximal epiphyseal cartilage width, according to GREENSPAN's procedure ${ }^{())}$.

\section{RESULTS AND DISCUSSION}

1. Changes in nucleic acid and total nitrogen content; As shown in TABLE 1, successive administrations of Pitressin caused a decrease in DNA-P concentration in liver. In these Pitressin-treated rats, however, the weight of liver increased

TABLE 1

Effect of posterior pituitary hormone on nucleic acid and total nitrogen contents in livers of normal and hypophysectomized rats

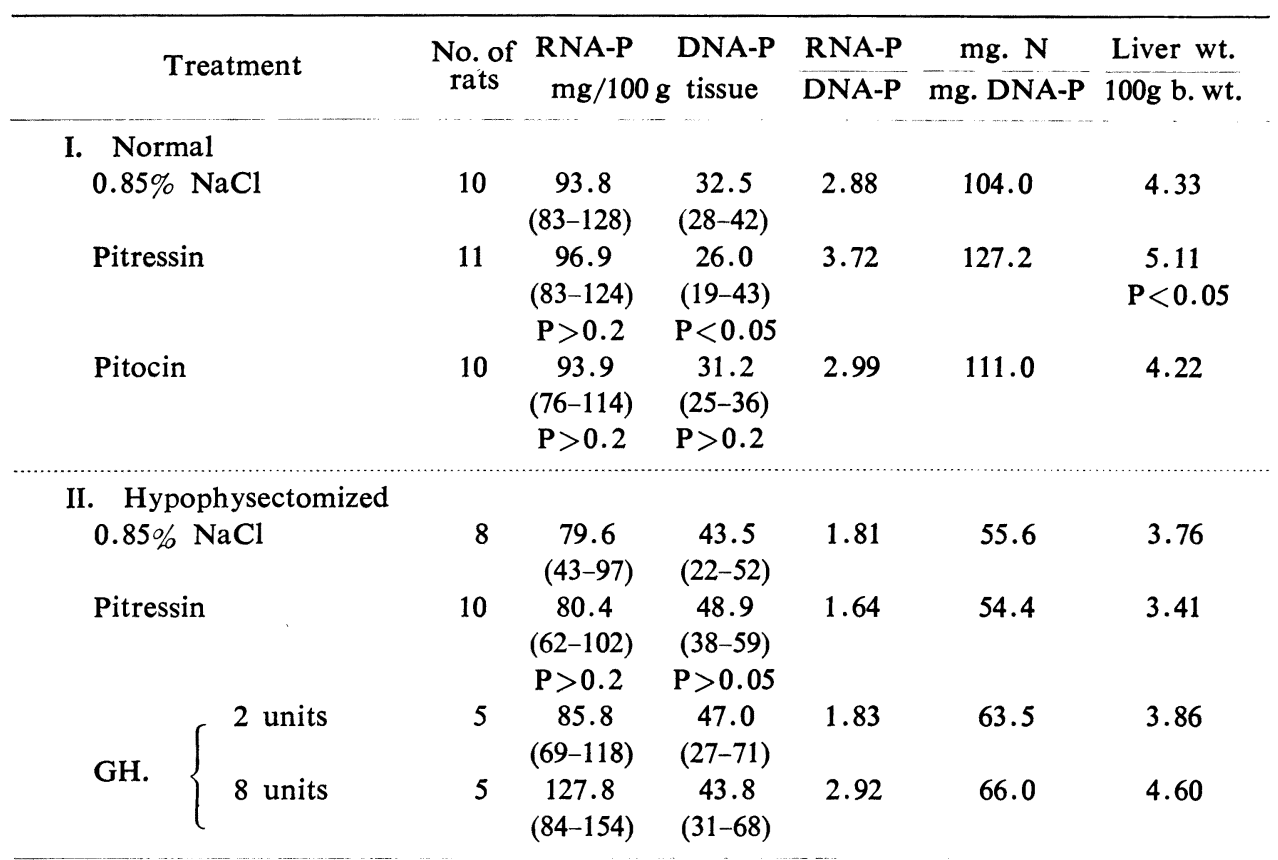

Figures in parentheses indicate range in each group. 
significantly. This indicates a hypertrophy of the liver cells, so that comparison of the concentration per unit weight of tissue seems to be not a proper way. The decreased DNA-P concentration in the hypertrophied liver may not indicate its actual reduction in the cells. Accordingly, the values obtained were corrected by the changes in liver weight, and it was calculated to amount to $30.7 \mathrm{mg} \mathrm{P} / 100 \mathrm{~g}$ fresh tissue in the Pitressin-treated rats; the value was not different from corresponding one of cortrol group (32.5 mg P). By the same correction RNA-P content in the liver of Pitressin-treated rats was calculated to be $114.4 \mathrm{mg} \mathrm{P}$, which revealed a significant increase $(P<0.05)$ from the control value of $93.8 \mathrm{mg} P$. The fact that the ratio RNA-P/DNA-P increased markedly from 2.88 to 3.72 may support the above inference for the significant increase in RNA-P. If the amounts of nucleic acids and total nitrogen were calculated in terms of content per organ in the above mentioned view, DNA-P content was constant in all groups, while RNA-P showed an increase of statistical significance in group of rats treated with Pitressin, accompanying an increase in nitrogen content from $146.0 \mathrm{mg} \mathrm{N}$ to $168.5 \mathrm{mg} \mathrm{N}$. On the other hand, chronic treatments with Pitocin did not cause any change in nucleic acid and nitrogen content in the liver at all (FIG. 1).

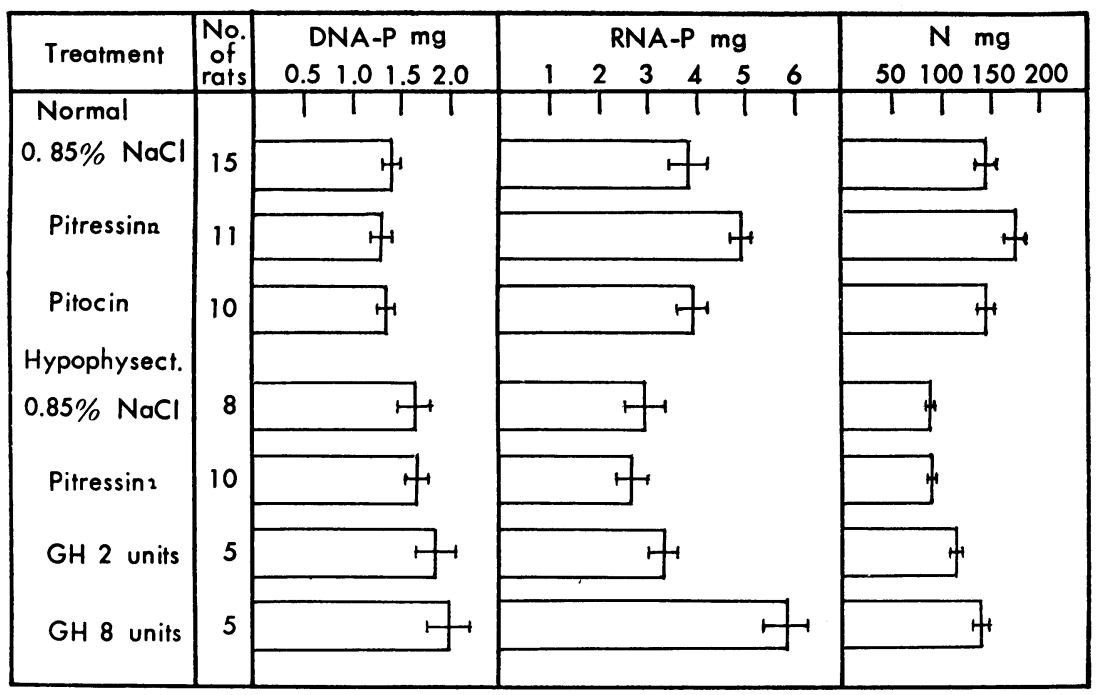

FIG. 1. Effect of posterior pituitary hormone on nucleic acid and total nitrogen contents in livers of normal and hypophysectomized rats. The contents were expressed as $\mathrm{mg}$ per organ (see text).

In another series of experiments hypophysectomized rats were treated with Pitressin, in an attempt to know whether this hormone acts directly on liver cells, increasing RNA-P content, or indirectly. Results were expressed as content per organ, as shown in FIG. 1. It may be manifest that hypophysectomy had little 
influence on DNA-P content in the liver at least within a period of 20 days after the operation. Contrary to the results with normal rats, in the hypophysectomized rats administration of Pitressin did not bring about any changes in both RNA-P and total nitrogen contents, while treatments with growth hormone caused marked increases in the contents. The pronounced effect of growth hormone on the livers of hypophysectomized rats was also shown in rises of the ratio RNA-P/DNA-P and the liver weight.

The fact that Pitressin exhibits the effect only in the presence of the functioning pituitary gland indicates that the action of this hormone on the liver is mediated through the anterior pituitary secretion. It is known that growth hormone exerts a similar influence on liver cells as Pitressin does. According to Geschwind et al..$^{7)}$ and Di STEFANo et al. ${ }^{8-10)}$, hypophysectomy resulted in a marked fall in RNA and protein contents in liver cells, but no change in DNA per nucleus of the cells and growth hormone treatment of hypophysectomized rats restored the liver RNA content to or above normal. On the basis of these findings, as a possible mechanism by which Pitressin produces increases in RNA and total nitrogen contents in liver, growth hormone discharge from the anterior pituitary gland may be presumed.

2. Changes in proximal epiphyseal cartilage width of tibia; Possibility of growth hormone discharge due to vasopressin was first suggested by MARTINI et al. ${ }^{11)}$ They measured the width of proximal epiphyseal cartilage of tibias of rats treated with posterior pituitary hormone, and found a significant enlargement of it in normal rats after administration of vasopressin, but not after oxytocin. On the other hand, in hypophysectomized rats posterior pituitary hormone was ineffective to produce any modification of the epiphyseal cartilage. In the present experiments these findings were confirmed. As shown in TABLE 2, the width of epiphyseal

TABLE 2

Effect of posterior pituitary hormone on epiphyseal cartilage width in normal and hypophysectomized rats

\begin{tabular}{|c|c|c|c|}
\hline & Treatment & $\begin{array}{l}\text { No. of } \\
\text { rats }\end{array}$ & $\begin{array}{c}\text { Width of epiphyseal cartilage } \\
\mu \text { (range) }\end{array}$ \\
\hline \multirow[t]{4}{*}{ I. } & Normal & & \\
\hline & $0.85 \% \mathrm{NaCl}$ & 9 & $177(160-195)$ \\
\hline & Pitressin & 13 & $233(180-307) \mathrm{P}<0.001$ \\
\hline & Pitocin & 10 & $193(130-230) \mathrm{P}>0.20$ \\
\hline \multirow[t]{5}{*}{ II. } & Hypophysectomized & & \\
\hline & $0.85 \% \mathrm{NaCl}$ & 8 & $111(96-123)$ \\
\hline & Pitressin & 10 & $109(94-118) P>0.20$ \\
\hline & GH $\int 2$ units & 5 & $214(206-222) \mathrm{P}<0.001$ \\
\hline & GH. $\{8$ units & 5 & $308(260-375) \mathrm{P}<0.001$ \\
\hline
\end{tabular}

Figures in parentheses indicate range in each group. 
cartilage was $177 \pm 10.5 \mu$ in control rats and it increased to $233 \pm 12.1 \mu$ after 10 days treatments with Pitressin $(P<0.001)$. Pitocin had no effect; the width remained unchanged after treatments with this hormone $(P>0.20)$. In hypophysectomized rats Pitressin did not produce any alteration (control $111 \pm 4.5 \mu$; after Pitressin $109 \pm 7.2 \mu$ ), while growth hormone induced a marked enlargement of it. In case of daily dose of 2 units growth hormone for 4 days it became $214 \pm 5.4 \mu$, and in case of 8 units it increased to $308 \pm 7.3 \mu$.

3. Effect of cortisone on nucleic acid content; In the above experiments it was noticed that the adrenal weight increased from $23.8 \pm 0.64 \mathrm{mg} / 100 \mathrm{~g}$ body weight to $34.0 \pm 2.6 \mathrm{mg}$ after treatments with Pitressin. Such a hypertrophy of the adrenal gland is presumably caused by ACTH discharge, since vasopressin stimulates the secretion of ACTH affecting the anterior pituitary gland and calls forth the discharge of adrenocortical hormone ${ }^{2)}$. It was also reported that treatments with cortisone cause a hypertrophy of liver ${ }^{12-14)}$ and an increase in RNA content ${ }^{13,14)}$. Therefore, the effect of Pitressin on liver nucleic acid may result from the activation of the pituitary-adrenal system.

The following experiment was undertaken to know the effect of adrenocortical hormone on nucleic acid content in liver. That is, cortisone acetate was given to normal rats in daily dose of $5 \mathrm{mg} / 100 \mathrm{~g}$ body weight for 5 days. As shown in TABLE 3, after these treatments a marked increase of liver weight from $4.3 \pm 0.24 \mathrm{~g}$

TABLE 3

Effect of cortisone on nucleic acid content in livers of normal rats

\begin{tabular}{|c|c|c|c|c|c|c|c|}
\hline \multirow{3}{*}{ Treatment } & \multirow{3}{*}{$\begin{array}{l}\text { No. } \\
\text { of } \\
\text { rats }\end{array}$} & \multicolumn{2}{|c|}{ DNA-P } & \multicolumn{2}{|c|}{ RNA-P } & \multirow{3}{*}{$\begin{array}{l}\text { RNA-P } \\
\text { DNA-P }\end{array}$} & \multirow{3}{*}{$\frac{\text { Liver wt. }}{100 \mathrm{~g} \text { b.wt. }}$} \\
\hline & & & total con- & & total con- & & \\
\hline & & $\underset{\text { tissue }}{\mathrm{mg} / 100 \mathrm{~g}}$ & $\begin{array}{l}\text { tent mg/ } \\
100 \mathrm{~g} \mathrm{b.wt} .\end{array}$ & $\underset{\text { tissue }}{\mathrm{mg} / 100 \mathrm{~g}}$ & $\begin{array}{c}\text { tent mg/ } \\
100 \mathrm{~g} \mathrm{b.wt} .\end{array}$ & & \\
\hline Cortisone & 8 & $\begin{array}{c}17.4 \\
(14-21)\end{array}$ & $\begin{array}{c}1.42 \\
(0.92-1.80)\end{array}$ & $\begin{array}{c}60.1 \\
(43-76)\end{array}$ & $\begin{array}{c}4.57 \\
(2.48-6.65)\end{array}$ & 3.45 & 8.2 \\
\hline Control & 10 & $\begin{array}{c}32.5 \\
(28-42)\end{array}$ & $\begin{array}{c}1.40 \\
(1.00-1.98)\end{array}$ & $\begin{array}{c}93.8 \\
(83-128)\end{array}$ & $\begin{array}{c}3.84 \\
(2.64-4.95)\end{array}$ & 2.88 & 4.3 \\
\hline Fisher's te & t $\mathbf{P}$ & $<0.001$ & $>0.20$ & $<0.01$ & $>0.20$ & & \\
\hline
\end{tabular}

Figures in parentheses indicate range in each group.

to $8.2 \pm 0.64 \mathrm{~g}$ was found. Concentrations of DNA-P and RNA-P decreased apparently; however, if these values were calculated in terms of content per organ as previously explained, DNA-P content remained unchanged and a tendency of increase in RNA-P content was statistically not significant $(P>0.20)$. These results obtained in rats treated with cortisone are actually different from those observed after Pitressin in respect of a less increase in RNA content in spite of a marked weight gain.

The evidence presented in the experiments of nucleic acid content in liver 
may not be sufficient to rule out all the possibilities that the enhanced secretion of steroid hormone is associated with the effect of Pitressin on the liver cells. However, results of the experiments on the epiphyseal cartilage width substantially suggest growth hormone discharge due to Pitressin.

Pitressin may not affect gonadotropin discharge from the anterior pituitary gland. Recent study of our laboratory showed that Pitressin induces a marked increase in urinary excretion of 17-ketosteroids not only in normal male and female rats, but also in castrated ones. Fractionation of 17-ketosteroids in urine of normal male subjects indicated little change in steroid fraction derived from testes, but considerable increase in that from adrenal cortex, after Pitressin administration $^{15)}$. Furthermore, it was found that Pitressin did not cause any alteration in nucleic acid and total nitrogen content in testes of rats (unpublished data). From these observations it may be inferred that protein anabolic action of testicular hormone is not involved in the present results.

\section{SUMMARY}

1. Chronic treatments with Pitressin produced increases in RNA-P and total nitrogen contents in livers of normal rats, while DNA-P content remained unchanged. Pitocin had no effect.

2. After hypophysectomy RNA-P and total nitrogen contents in liver reduced considerably; administration of growth hormone restored the decreased contents toward normal level, while Pitressin was ineffective.

3. Chronic treatments with Pitressin induced a significant enlargement of epiphyseal cartilage width of tibia in normal rats. Pitocin had no effect.

4. In hypophysectomized rats the width was markedly reduced; growth hormone, but not Pitressin, restored the narrowed width toward normal.

5. Administration of cortisone acetate produced a marked gain in liver weight and a slight increase in RNA-P content.

The authors are indebted to Dr. A. Arimura for Pitressin and Pitocin.

\section{REFERENCES}

1) Chargaff, E. And Davidson, J. N. The Nucleic Acids, Vol. II, 32: Academic Press, New York, 1955.

2) Ітон, S. Hokkaido J. Med. Sci. 33: 73, 1958 (Japanese).

3) Schneider, W. C. J. Biol. Chem. 161: 293, 1945.

4) Dische, Z. Microchemie 8: 4, 1930.

5) Mejbaum, W. Z. physiol. Chem. 258: 117, 1939.

6) Greenspan, F. S., Li, C. H., Simpson, M. E. and Evans, H. M. Endocrinology 45: 455, 1949.

7) Geschwind, I., Li, C. H. And Evans, H. M. Arch. Biochem. 28: 73, 1950.

8) Di Stefano, H. S., Bass, A. D., Diermeier, H. F. ANd Tepperman, J. Endocrinology 
51: 386, 1952.

9) Di Stefano, H. S., Diermeier, H. F. ANd Tepperman, J. Endocrinology 57: 158, 1955.

10) Di Stefano, H. S. ANd Diermeier, H. F. Endocrinology 64: 448, 1959.

11) Del Vecchio, A., Genovese, E. and Martini, L. Proc. Soc. Exp. Biol. Med. 98: $641,1958$.

12) Eisenstein, A. B. Biochem. Biophys. Acta $36:$ 580, 1959.

13) Lowe, C. U., Williams, W. L. and Thomas, L. Proc. Soc. Exp. Biol. Med. 78: 818, 1951.

14) Silber, R. H. ANd Porter, C. C. Endocrinology 52: 518, 1953.

15) Tsujioka, K., Kanayama, N. and Saito, H. Hokkaido J. Med. Sci. (in press). 